\title{
Salmonella enterica subspecies arizonae infection of adult patients in Southern Taiwan: a case series in a non-endemic area and literature review
}

Yi-Chien Lee ${ }^{1}$, Miao-Chiu Hung ${ }^{2}$, Sheng-Che Hung ${ }^{3,4}$, Hung-Ping Wang ${ }^{1}$, Hui-Ling Cho ${ }^{5}$, Mei-Chu Lai ${ }^{6}$ and Jann-Tay Wang ${ }^{7^{*}}$

\begin{abstract}
Background: The majority of Salmonella arizonae human infections have been reported in southwestern United States, where rattlesnake-based products are commonly used to treat illness; however, little is known in non-endemic areas. We reviewed and analyzed the clinical manifestations and treatment outcomes in adult patients with S. arizonae infection at our institution.

Method: A retrospective study was conducted at a regional teaching hospital in southern Taiwan from July 2007 to June 2014. All adult patients diagnosed with S. arizonae infections and treated for at least three days at Chia-Yi Christian Hospital were included. Patients were followed till discharge.

Results: A total of 18 patients with S. arizonae infections (median age: 63.5 years) were enrolled for analysis, of whom two thirds were male. The three leading underlying diseases were diabetes mellitus, peptic ulcer disease and malignancy. Ten patients had bacteraemia and the most common infection focus was the lower respiratory tract. Most of the patients (72.2\%) received third-generation cephalosporins as definitive therapy. In contrast, ampicillin-based regimens (accounting for 45.2\%) were the major treatment modalities in previous reports. The crude in-hospital mortality was 5.6\%, which was much lower than what was previously reported (22.7\%).

Conclusions: Though uncommon, there were cases of $\mathrm{S}$. arizonae infections in Taiwan. Patients receiving thirdgeneration cephalosporins treatment had better prognosis compared with those treated with ampicillin-based regimen.
\end{abstract}

Keywords: Salmonella arizonae, Peptic ulcer disease, Proton pump inhibitors, Third generation cephalosporins, Ampicillin

\section{Background}

Salmonellae are Gram-negative, non-spore-forming, facultatively anaerobic bacilli belonging to the family of Enterobacteriaceae, which usually cause food-borne diseases. Salmonella arizonae, one of the less common members of Salmonellae, has the distinguishing biochemical characteristics of the ability to ferment lactose, utilize malonate, liquefy gelatin, and inhibition by the presence of potassium cyanide [1]. It was first reported in diseased

\footnotetext{
* Correspondence: 14bcr@yahoo.com.tw

${ }^{7}$ Department of Internal Medicine, National Taiwan University Hospital, No. 7 Chung-Shan South Road, Taipei 10002, Taiwan

Full list of author information is available at the end of the article
}

reptiles in 1939 by Caldwell and Ryerson, and was named Salmonella dar-es-salaam at that time [2]. It has also been subsequently named Arizona hinshawii, S. arizonae, S. cholerasuis subsp. arizonae and finally reclassified as $S$. enterica subsp. arizonae in 1983 (S. arizonae was used throughout this manuscript) [3].

It was initially considered to be pathogenic only in reptiles, especially in snakes, with as many as $78.8 \%$ of them harboring the organism [4]. It was occasionally responsible for severe outbreaks in turkeys and sheep [4]. The first case of human infection by $S$. arizonae, presented with gastroenteritis, was recognized in 1944 [5]. Thereafter, S. arizonae was noted to be able to cause a 
spectrum of human diseases, including gastroenteritis, bacteraemia, vascular infection, bone and joint infection, and central nervous system infection [1, 4, 6-22]. Most of these infections have a good prognosis without any complications. However, severe human infection caused by $S$. arizonae has been documented in children below 7 years of age [23], immunocompromised adults, (e.g., autoimmune diseases under steroid therapy $[1,8,10,11$, $14,24,25]$, malignancy [7, 13, 14, 21, 26-29], human immunodeficiency virus (HIV) infection $[1,15,17,19$, $30,31]$, organ transplantation $[11,32])$, or even in immunocompetent populations [18].

Cold-blooded animals are the usual habitats of $S$. arizonae, especially in reptiles or rattlesnake-based products. Other animals, including poultry, rats, and dogs $[6,9,17]$, have also been involved in human infection by $S$. arizonae. According to previously published articles $[1,10,13,14,16,25-29,31]$, the geographic distributions of $S$. arizonae human infections are mainly located in south-western United States, where the use of rattlesnake-associated products to treat a wide variety of illnesses is popular among Mexican-Americans populations. Around 20 pediatric patients below 18 years of age suffering from $S$. arizonae infection have been reported in the literature $[9,17,21,23]$. Little is known about S. arizonae infection of adult patients in Asian countries, including Taiwan. The aim of this study was to analyze all adult patients with $S$. arizonae infection at a regional teaching hospital in southern Taiwan and to perform a literature review on similar patients.

\section{Methods}

From July 2007 to June 2014, all adult patients ( $\geq 18$ years) diagnosed with $S$. arizonae infection and treated for at least 3 days at Chia-Yi Christian Hospital $(\mathrm{CYCH}$, a regional teaching hospital with a capacity of 1000 beds in southern Taiwan) were retrospectively enrolled. S. arizonae infection was defined as positive cultures of any kind of clinical specimens, including blood, pleural effusion, ascites, urine, sputum, stool, pus and bone, for S. arizonae plus the presence of signs of systemic or local infection. All types of specimens were collected, transported, and processed according to the suggestion described previously [33], and then inoculated into the corresponding culture media for subsequent incubation [34]. The blood culture system at $\mathrm{CYCH}$ was Bactec FX system (Becton, Dickinson and Co. [BD], Franklin Lakes, NJ). All bone tissues were collected by bone biopsy or surgical procedures. Potential pathogens were identified by Vitek version 2.0 (bio Merieux Suisse S.A., Geneva, Switzerland), and Salmonella isolates were confirmed by serologic testing (Difco $^{\mathrm{TM}}$ Antiserum Solutions). The culture-positive cases were identified by reviewing microbiology records at $\mathrm{CYCH}$.
A standardized case report form was used to collect the demographics, clinical and laboratory data and treatment outcomes. Patients who used $\mathrm{H}_{2}$-receptor antagonists or proton pump inhibitors within one month prior to admission were defined as having peptic ulcer disease. Leukocytosis was defined as white blood cell counts exceeding $10 \mathrm{~K} / \mu \mathrm{l}$ and thrombocytopenia was defined as platelet count below $150 \mathrm{~K} / \mu \mathrm{l}$. The infection foci of non-bacteraemic patients and patients with secondary bacteraemia were determined if there was a presence of clinical symptoms or signs of infection and isolation of $S$. arizonae from related clinical specimens. Bacteraemia without an obvious infection source or related to intravascular catheter infection or vascular lesions was classified as primary bacteraemia.

The antimicrobial susceptibilities to chloramphenicol, ciprofloxacin, trimethoprim/sulfamethoxazole, ampicillin and ceftriaxone were determined using the disk diffusion method according to the recommendation of the Clinical and Laboratory Standards Institute (CLSI) [35]. The results were also interpreted using the criteria suggested by CLSI [36]. Antimicrobial agents given before the susceptibility results were defined as empirical therapy, whereas definitive therapy was defined as effective antibiotic therapy prescribed according to the results of final blood cultures and susceptibility testing. The study was approved by the ethics review boards of the hospital [Chia-Yi Christian Hospital-Institutional Review Board (CYCH-IRB) No. 104035, 06/30/2015]. The IRB waived informed consent due to the retrospective study design and the research posing no more than minimal risk.

Continuous variables were described as medians with interquartile ranges (IQR) and categorical variables were described as percentage.

\section{Results}

A total of 485 adult patients with Salmonella species infection were identified during this seven-year period, and only $4.7 \%$ (23/485) of those patients suffered from $S$. arizonae infection. Five among them were excluded because they received treatment for less than 3 days at $\mathrm{CYCH}$ and did not follow-up subsequently. For the five eliminated patients, the median age was 65 years (IQR, 60-72 years). Four of them had primary bacteraemia and one had pneumonia. The demographics, clinical features, laboratory data and treatment outcome of the enrolled 18 patients are showed in Table 1. Of these 18 patients, the median age was 63.5 years, ranging from 27 to 81 years, with 12 men and six women. All patients lived in Chiayi City, except one, who lived in Yunlin County. All patients had various underlying diseases, including endocrine diseases in 12 (66.7\%; diabetes mellitus in ten, and another diseases in two), peptic ulcer disease in eight (44.4\%), malignancy in eight (34.8\%; hepatocellular 
Table 1 Demographics and clinical data of 18 patients with S. arizonae infections in our case series

\begin{tabular}{|c|c|}
\hline Age by years (median, range) & $63.5(27-81)$ \\
\hline Male to female ratio & $12: 6$ \\
\hline \multicolumn{2}{|l|}{ Underlying diseases (No., \%) } \\
\hline Diabetes mellitus & $10(55.6)$ \\
\hline Hypothyroidism & $2(11.1)$ \\
\hline Peptic ulcer diseases & $8(44.4)$ \\
\hline Hepatocellular carcinoma & $4(22.2)$ \\
\hline Lung cancer & $3(16.7)$ \\
\hline Colon cancer & $1(5.6)$ \\
\hline Multiple myeloma & $1(5.6)$ \\
\hline Hypertension & $7(38.9)$ \\
\hline Liver cirrohosis & $6(33.3)$ \\
\hline Hepatitis B & $5(27.8)$ \\
\hline Hepatitis C & $2(11.1)$ \\
\hline Chronic kidney diseases & $3(16.7)$ \\
\hline Systemic lupus erythematosus & $1(5.6)$ \\
\hline AIDS & $1(5.6)$ \\
\hline \multicolumn{2}{|l|}{ Symptoms (No., \%) } \\
\hline Fever & $9(50.0)$ \\
\hline Abdominal discomfort & $7(38.9)$ \\
\hline Dyspnea & 7 (38.9) \\
\hline \multicolumn{2}{|l|}{ Laboratory data (No., \%) } \\
\hline WBC $>10000 / \mu l$ & $10(55.6)$ \\
\hline $\mathrm{CRP}>10 \mathrm{mg} / \mathrm{dL}$ & $8 / 17(47.1)$ \\
\hline $\mathrm{ALT}>44 \mathrm{U} / \mathrm{L}$ & $8 / 17(47.1)$ \\
\hline Creatinine $>1.3 \mathrm{mg} / \mathrm{dl}$ & $7 / 17(41.2)$ \\
\hline \multicolumn{2}{|l|}{ Site of bacterial isolation (No., \%) } \\
\hline Blood & $10(55.6)$ \\
\hline Bone & $2(11.1)$ \\
\hline Abscess & $2(11.1)$ \\
\hline Pleural effusion & $2(11.1)$ \\
\hline Sputum & $1(5.6)$ \\
\hline Stool & $1(5.6)$ \\
\hline Ascites & $1(5.6)$ \\
\hline Urine & $1(5.6)$ \\
\hline \multicolumn{2}{|l|}{ Clinical presentations (No., \%) } \\
\hline Lower respiratory tract infection & $4(22.2)$ \\
\hline Bone and joint infection & $3(16.7)$ \\
\hline Gastrointestinal tract infection & $3(16.7)$ \\
\hline Intra-abdominal infection/peritonitis & $3(16.7)$ \\
\hline Soft tissue infection & $2(11.1)$ \\
\hline Mycotic aneurysm & $2(11.1)$ \\
\hline Urinary tract infection & $1(5.6)$ \\
\hline
\end{tabular}

Table 1 Demographics and clinical data of 18 patients with S. arizonae infections in our case series (Continued)

\begin{tabular}{|c|c|}
\hline \multicolumn{2}{|c|}{ Definite antibiotic treatment (No., \%) } \\
\hline $3^{\text {rd }}$ generation cephalosporins & $13(72.2)$ \\
\hline Fluoroquinolones & $3(16.7)$ \\
\hline Piperacillin/tazobactam & $1(5.6)$ \\
\hline TMP/SMX & $1(5.6)$ \\
\hline Intensive care unit stay (No., \%) & $9(50.0)$ \\
\hline $\begin{array}{l}\text { Length of hospitalization, days } \\
\text { (mean } \pm \text { standard deviation) }\end{array}$ & $19.7 \pm 13.7$ \\
\hline In-hospital mortality (No., \%) & $1(5.6)$ \\
\hline
\end{tabular}

carcinoma in four, lung cancer in three, and colon cancer in one), hypertension in seven (38.9\%), liver cirrhosis in six (33.3\%), chronic viral hepatitis in six (33.3\%; hepatitis B virus in five, and hepatitis $\mathrm{C}$ virus in two), chronic kidney disease in three (16.7\%), autoimmune diseases in one, and acquired immunodeficiency syndrome in one (5.6\%).

Nine patients $(50.0 \%)$ had fever as their first presentations. The other initial presentations included abdominal discomfort $(7 / 18,38.9 \%)$, dyspnoea $(7 / 18,38.9 \%)$, cough $(3 / 18,16.7 \%)$, diarrhea $(3 / 18,16.7 \%)$, change in consciousness $(2 / 18,11.1 \%)$, and arthralgia $(2 / 18,11.1 \%)$. The median initial body temperature was $37.2{ }^{\circ} \mathrm{C}$ (IQR, $36.1-38.3)$ and 14 patients $(77.8 \%)$ had initial heart rates above 90 beats per minute. Hypotension (systolic blood pressure $<90 \mathrm{mmHg}$ ) occurred in three patients. Leucocytosis was noted in ten patients $(55.6 \%)$, and nine (50.0\%) patients had thrombocytopenia. Seventeen patients had neutrophilia and eight patients $(47.1 \%$, one missing data) had elevated C-reactive protein levels of up to more than $10 \mathrm{mg} / \mathrm{dL}$. For liver function tests, 11 patients $(64.7 \%)$ had elevated aspartate or alanine transaminase values (AST > $38 \mathrm{U} / \mathrm{L}$ or ALT $>44 \mathrm{U} / \mathrm{L}$ ). Impaired renal function at presentation, defined as serum creatinine $>1.3 \mathrm{mg} / \mathrm{dl}$, was noted in $41.2 \%$ ( $7 / 17$, one missing data) of patients. Initial serum albumin level was available in 13 patients only and 11 of them $(84.6 \%)$ had hypoalbuminemia (albumin $<3 \mathrm{~g} / \mathrm{dL}$ ). Hyponatremia (sodium $<135 \mathrm{mmol} / \mathrm{L}$ ) was found in $82.4 \%$ of patients (14/17, one missing data), and only four patients (23.5\%, one missing data) had hypokalaemia (potassium $<3.5 \mathrm{mmol} / \mathrm{L}$ ). Serum glucose level at presentation was only available in 13 patients, and five $(38.5 \%)$ of them had elevated levels of $\geq 200 \mathrm{mg} / \mathrm{dL}$.

Blood cultures were obtained in all 18 patients, and bacteraemia was identified in ten (55.6\%), including primary bacteraemia in two, both with mycotic aneurysm and secondary bacteraemia in eight. The most common infection foci of patients with secondary bacteraemia and non-bacteraemic clinical syndromes were lower respiratory 
tract $(4 / 18,22.2 \%)$, followed by bone and joint $(n=3$, $16.7 \%)$, gastrointestinal tract $(n=3,16.7 \%)$, intraabdominal infection or peritonitis $(n=3,16.7 \%)$, soft tissue $(n=2,11.1 \%)$, and urinary tract $(n=1,5.6 \%)$. In-vitro susceptibility testing revealed that all isolates were susceptible to all of the five tested antimicrobials, i.e. no strains had decreased susceptibility to ciprofloxacin according to the 2013 CLSI guidelines. Seven patients received effective empirical antibiotics. The definite therapy included third-generation cephalosporins in 13 (72.2\%) of 18 patients, of which three patients received combined therapy (oral co-trimoxazole in two and ciprofloxacin in one), fluoroquinolone in three (16.7\%), piperacillin/tazobactam in one (5.6\%), and oral cotrimoxazole in one $(5.6 \%)$. The median duration of treatment with parenteral antibiotics was 12 days, ranging from 5 to 62 days. Of the 18 patients, the median hospital stay was 14 days, ranging from 6 to 62 days. Nine $(50.0 \%)$ patients were admitted to the intensive care unit during their hospitalization. 17 patients recovered from this infection successfully after completion of the treatment course, and one patient died. Overall, the crude in-hospital mortality rate was $5.6 \%(1 / 18)$.

\section{Discussion}

Our present study demonstrates that $S$. arizonae infection is uncommon among adult patients with a crude inhospital mortality rate of $5.6 \%$. To the best of our knowledge, this is the largest case series reporting adult patients infected by $S$. arizonae. Based on a thorough search in PubMed, there were 27 studies reporting and discussing patients with S. arizonae infection from 1959 to the writing of the present manuscript. Clinical characteristics of these 44 reported patients, including age, gender, underlying diseases, type of infection, antibiotic therapy, exposure and treatment outcome, are displayed in Table 2.

Patients in the present study were either elderly male or had various underlying conditions (Table 1) which would compromise their cell-mediated immunity. In the literature (Table 2), the most commonly reported comorbidities associated with $S$. arizonae infections were immunocompromised status, including connective tissue diseases under steroid therapy (40.9\%), malignancy $(27.3 \%)$ and acquired immunodeficiency syndrome (13.6\%) $[15,17]$. Our case series produced similar findings. Additionally, we identified three more associated host underlying conditions, including type 2 diabetes mellitus, liver cirrhosis, and peptic ulcer disease. Uncontrolled diabetes and liver cirrhosis have been shown to cause impairment of humoral- and cellmediated immunity, which play important roles in clearing Salmonella [37]. Therefore, these two diseases would reasonably predispose to the development of $S$. arizonae infection. Moreover, patients with peptic ulcer diseases received acid suppressants to treat their diseases. Usage of acid suppressants would not only decrease the acidity of gastric juice, which in turn might result in intestinal bacterial overgrowth, facilitate bacterial translocation from the intestine and lead to infection via the gastro-intestinal route [38], but also reduce the gastric acid barrier with subsequent infection despite a lower inoculum of bacteria. Similar findings have been previously reported by Wu et al. [39].

A variety of clinical manifestations were displayed in our series, including enterocolitis, bacteraemia, vascular infection and localized infections. The rank order of infection syndromes in our reports was bacteraemia, intraabdominal infection, and pulmonary infection. In contrast, bacteraemia $[1,7,10,13-15,17-19,21,22,26,28$, 30-32], intra-abdominal infection $[4,6,10-12,14,17$, $21,24,27,29,30,32,40]$ and bone or joint infection [8, $9,11,12,14,20,21,24]$ were the most common clinical manifestations in previously-reported patients (Table 2). Much fewer patients with bone and joint infection $(16.7 \%)$ were noted in our present study. Interestingly, both of the two patients in our series diagnosed as $S$. arizonae related mycotic aneurysm with bacteraemia had a past history of hypertension. This is similar to the result by Wang JY et al., who demonstrated that hypertension was the major factor predisposing to $S$. choleraesuis mycotic aneurysm [41]. Importantly, our study is the first one to demonstrate that soft tissue could be the infection focus of $S$. arizonae, which was observed in two of our patients. Overall, the difference in clinical manifestations between our study and prior reports might be due to the small number of patients enrolled in every study. Therefore, further study is needed to clarify whether geographic variance or other factors were associated with the difference of clinical syndromes.

All S. arizonae isolates collected in the present study were susceptible to all five of the recommended antiSalmonella agents, including chloramphenicol, ciprofloxacin, trimethoprim/sulfamethoxazole, ampicillin, and ceftriaxone. These five antimicrobial agents have the ability to penetrate host cells, which is crucial in killing intra-cellular pathogens, such as Salmonella. All of our patients received at least one of these five agents as their definite therapy, among which third-generation cephalosporins were prescribed for the majority of patients $(72.2 \%$, Table 1$)$. Instead, ampicillin was usually chosen as the backbone of the treatment modality (45.2\%) in previously published articles (Table 2 ). Although the difference was not statistically significant $(p=0.1$ by chi-square test), the crude in-hospital mortality rate was only $5.6 \%$ in the present study, which was much lower than that $(10 / 44,22.7 \%)$ of the prior reports (Table 2). In particular, 6 of the 10 fatal patients in prior reports received ampicillin as their treatment against $S$. arizonae infection. Therefore, a third-generation cephalosporin could potentially be a better choice for treating S. arizonae 
Table 2 Characteristics, clinical diseases and outcome of 44 human infections with S. arizonae reported in the literature (1959-2012)

\begin{tabular}{|c|c|c|c|c|c|c|c|}
\hline Reference & Age & Gender & Underlying Diseases & Type of Infection & Antibiotic Treatment & Exposure & Outcome \\
\hline Krag 1959 [20] & 63 & $\mathrm{~F}$ & $\begin{array}{l}\text { idiopathic thrombocytopenic } \\
\text { purpura }\end{array}$ & knee septic arthritis & achromycin & unknown & death \\
\hline Guckian 1967 [24] & 52 & F & SLE, DM & $\begin{array}{l}\text { knee septic arthritis/ } \\
\text { gastroenteritis/UTI }\end{array}$ & $\begin{array}{l}\text { cephalothin/ampicillin/ } \\
\text { chloramphenicol }\end{array}$ & unknown & recover \\
\hline Andrews 1970 [6] & 21 & M & none & gastroenteritis & $\begin{array}{l}\text { ampicillin/ } \\
\text { chloramphenicol }\end{array}$ & dog & recover \\
\hline Smilack 1975 [8] & 23 & $\mathrm{~F}$ & SLE & $\begin{array}{l}\text { knee/shoulder arthritis/ } \\
\text { tibial abscess }\end{array}$ & ampicillin/cephalothin & unknown & recover \\
\hline Arora 1976 [18] & 30 & M & none & bacteraemia & chloramphenicol & unknown & recover \\
\hline Keren 1976 [12] & 53 & M & alcoholism & $\begin{array}{l}\text { osteomyelitis/ } \\
\text { gastroenteritis }\end{array}$ & $\begin{array}{l}\text { ampicillin/ } \\
\text { aminoglycoside }\end{array}$ & unknown & recover \\
\hline Johnson 1976 [32] & 29 & M & Hodgkin's disease & $\begin{array}{l}\text { bacteraemia/ } \\
\text { gastroenteritis/UTI }\end{array}$ & ampicillin & raw milk & death \\
\hline Johnson 1976 [32] & 54 & M & post heart transplant & $\begin{array}{l}\text { bacteraemia/ } \\
\text { gastroenteritis }\end{array}$ & $\begin{array}{l}\text { cephalothin/ } \\
\text { gentamicin }\end{array}$ & unknown & death \\
\hline Johnson 1976 [32] & 54 & $\mathrm{~F}$ & mental retardation & $\begin{array}{l}\text { gastroenteritis/ } \\
\text { pneumonia/ } \\
\text { empyema }\end{array}$ & ampicillin & unknown & recover \\
\hline Petru 1981 [22] & 53 & M & DM/interstitial pneumonitis & $\begin{array}{l}\text { bacteraemia/mycotic } \\
\text { aneurysm }\end{array}$ & ampicillin/gentamicin & NA & recover \\
\hline Lindsay 1981 [40] & 69 & $\mathrm{~F}$ & cirrhosis & bacteraemia/peritonitis & $\begin{array}{l}\text { cephalosporin/ } \\
\text { aminoglycoside/ } \\
\text { chloramphenicol }\end{array}$ & unknown & death \\
\hline Fainstein 1982 [13] & 66 & M & leukaemia & bacteraemia & $\begin{array}{l}\text { ticarcillin/ } \\
\text { aminoglycoside }\end{array}$ & $\begin{array}{l}\text { rattlesnake } \\
\text { capsule }\end{array}$ & death \\
\hline Mcintyre 1982 [16] & 73 & M & DM/HTN & $\begin{array}{l}\text { septic arthritis/aortic } \\
\text { aneurysm/UTI }\end{array}$ & ampicillin & $\begin{array}{l}\text { rattlesnake } \\
\text { capsule }\end{array}$ & recover \\
\hline CDC 1983 [7] & 63 & $\mathrm{~F}$ & gallbaldder adenocarcinoma & bacteraemia & $?$ & $\begin{array}{l}\text { Rattlesnake } \\
\text { capsule }\end{array}$ & recover \\
\hline $\begin{array}{l}\text { Quismorio } 1983 \\
\text { [11] }\end{array}$ & 31 & $\mathrm{~F}$ & SLE & septic arthritis & ampicillin & unknown & death \\
\hline $\begin{array}{l}\text { Quismorio } 1983 \\
\text { [11] }\end{array}$ & 41 & M & HBV, post renal transplant & $\begin{array}{l}\text { septic arthritis/ } \\
\text { kidney abscess }\end{array}$ & ampicillin & unknown & death \\
\hline $\begin{array}{l}\text { Quismorio } 1983 \\
\text { [11] }\end{array}$ & 48 & $\mathrm{~F}$ & $\begin{array}{l}\text { Waldenstrom } \\
\text { macroglobulinemia }\end{array}$ & $\begin{array}{l}\text { septic arthritis/ } \\
\text { gastroenteritis/UTI }\end{array}$ & ampicillin & unknown & death \\
\hline Riley 1988 [1] & 19 & $\mathrm{~F}$ & SLE & bacteraemia & ampicillin & $\begin{array}{l}\text { rattlesnake } \\
\text { capsule }\end{array}$ & recover \\
\hline Riley 1988 [1] & 25 & M & AIDS & adenitis/empyema & TMP/SMX & $\begin{array}{l}\text { rattlesnake } \\
\text { capsule }\end{array}$ & recover \\
\hline Riley 1988 [1] & 51 & M & $\begin{array}{l}\text { HTN/DCM/CHF/atrial } \\
\text { fibrillation }\end{array}$ & pleurisy & nil & $\begin{array}{l}\text { rattlesnake } \\
\text { capsule }\end{array}$ & recover \\
\hline Bhatt 1989 [10] & 27 & $\mathrm{~F}$ & SLE & $\begin{array}{l}\text { bacteraemia/ } \\
\text { gastroenteritis/ } \\
\text { peritonitis/ } \\
\text { meningitis }\end{array}$ & ampicillin & rattlesnake meat & death \\
\hline $\begin{array}{l}\text { Fleischman } 1989 \\
\text { [28] }\end{array}$ & 38 & M & gastric carcinoma & bacteraemia/empyema & ampicillin & $\begin{array}{l}\text { rattlesnake } \\
\text { capsule }\end{array}$ & recover \\
\hline Jacobson 1989 [19] & 49 & $\mathrm{~F}$ & AIDS & bacteraemia & ciprofloxacin & unknown & recover \\
\hline Cone $1990[14]$ & 71 & $\mathrm{~F}$ & RA & $\begin{array}{l}\text { bacteraemia/arthritis/ } \\
\text { gastroenteritis }\end{array}$ & $\begin{array}{l}\text { ceftriaxone/ } \\
\text { chloramphenicol }\end{array}$ & folk remedy & recover \\
\hline Cone $1990[14]$ & 72 & M & metastatic melanoma & bacteraemia & aztreonam & $\begin{array}{l}\text { rattlesnake } \\
\text { capsule }\end{array}$ & recover \\
\hline Casner 1990 [31] & 30 & M & AIDS/Kaposi's sarcoma & bacteraemia/UTI & Baktar & $\begin{array}{l}\text { rattlesnake } \\
\text { capsule }\end{array}$ & recover \\
\hline
\end{tabular}


Table 2 Characteristics, clinical diseases and outcome of 44 human infections with S. arizonae reported in the literature (1959-2012) (Continued)

\begin{tabular}{|c|c|c|c|c|c|c|c|}
\hline Caravalho1990 [25] & 55 & $\mathrm{~F}$ & RA & endophthalmitis & cephalosporin & powder & recover \\
\hline Woolf 1990 [27] & 28 & $\mathrm{~F}$ & adenocarcinoma & peritonitis & ampicillin & capsule & death \\
\hline Babu 1990 [30] & 25 & M & AIDS/Kaposi's sarcoma & $\begin{array}{l}\text { bacteraemia/ } \\
\text { gastroenteritis/UTI }\end{array}$ & ciprofloxacin & $\begin{array}{l}\text { rattlesnake } \\
\text { powder }\end{array}$ & recover \\
\hline Noskin 1990 [15] & 57 & M & AIDS & bacteraemia & ampicillin & rattlesnake meat & recover \\
\hline Kraus 1991 [21] & 49 & $\mathrm{~F}$ & SLE & cholecystitis/bacteraemia & cephalothin/amikacin & $\begin{array}{l}\text { rattlesanke } \\
\text { capsule }\end{array}$ & recover \\
\hline Kraus 1991 [21] & 27 & $M$ & dermatomyositis & hip septic arthritis & ciprofloxacin & $\begin{array}{l}\text { rattlesnake } \\
\text { capsule }\end{array}$ & recover \\
\hline Kraus 1991 [21] & 34 & $\mathrm{~F}$ & SLE & knee septic arthritis & ciprofloxacin & $\begin{array}{l}\text { rattlesnake } \\
\text { capsule }\end{array}$ & recover \\
\hline Kraus 1991 [21] & 36 & $\mathrm{~F}$ & SLE & $\begin{array}{l}\text { knee/shoulder } \\
\text { septic arthritis/sepsis }\end{array}$ & ampicillin & $\begin{array}{l}\text { rattlesnake } \\
\text { capsule }\end{array}$ & recover \\
\hline Kraus 1991 [21] & 29 & $\mathrm{~F}$ & SLE & $\begin{array}{l}\text { knee/shoulder } \\
\text { septic arthritis/ } \\
\text { bacteraemia/UTI }\end{array}$ & ampicillin/amikacin & $\begin{array}{l}\text { rattlesnake } \\
\text { capsule }\end{array}$ & recover \\
\hline Kraus 1991 [21] & 24 & $\mathrm{~F}$ & leukaemia & bacteraemia & ciprofloxacin & unknown & recover \\
\hline Kraus 1991 [21] & 61 & $\mathrm{~F}$ & Primary biliary cirrhosis & vertebral osteomyelitis/UTI & ampicillin/amikacin & unknown & recover \\
\hline Kraus 1991 [21] & 25 & $\mathrm{~F}$ & SLE & UTI & $\mathrm{TMP} / \mathrm{SMX}$ & NA & recover \\
\hline Kraus 1991 [21] & 70 & $M$ & DM, ALS & bacteraemia & TMP/SMX & $\begin{array}{l}\text { rattlesnake } \\
\text { capsule }\end{array}$ & recover \\
\hline Sharma 1992 [29] & 69 & $M$ & gastric cancer & peritonitis & cefotaxime/gentamicin & rattlesnake pills & recover \\
\hline Cortes 1992 [26] & 60 & $M$ & metastatic carcinoma & bacteraemia/pneumonia & aztreonam & rattlesnake meat & recover \\
\hline Hoag 2005 [17] & 47 & $\mathrm{~F}$ & AIDS & $\begin{array}{l}\text { bacteraemia/pericarditis/ } \\
\text { gastroenteritis/UTI }\end{array}$ & ceftriaxone/ciproxin & pet chicken? & recover \\
\hline Di Bella 2011 [4] & 43 & M & $\begin{array}{l}\text { Hodgkin's disease/ } \\
\text { panhypoglobulinemia }\end{array}$ & gastroenteritis & ciprofloxacin & NA & recover \\
\hline S. Kolker 2012 [9] & 32 & $\mathrm{~F}$ & pemphigus & tibial abscess & ceftriaxone/ciproxin & iguana/snakes & recover \\
\hline
\end{tabular}

$F$ female, $M$ male, SLE systemic lupus erythematosus, DM diabetes mellitus, $H T N$ hypertension, $H B V$ hepatitis $B, A I D S$ acquired immunodeficiency syndrome, $D C M$ dilated cardiomyopathy, CHF congestive heart failure, RA rheumatoid arthritis, ALS amyotrophic lateral sclerosis, UTI urinary tract infection, TMP/SMX trimethoprim/sulfamethoxazole, NA not available

infection compared to ampicillin. However, further investigation is needed.

One patient in our study received piperacillin/tazobactam, which is not the recommended antibiotic as the definitive treatment against Salmonellae , and had a favorable outcome. Using piperacillin/tazobactam for Salmonella infection was rarely reported in previous articles. Bell SD demonstrated that minimal inhibitory concentration of piperacillin/tazobactam for S. arizonae isolated from this study was $\leqq 4 \mu \mathrm{g} / \mathrm{mL}$ [4], implicating the bacterium susceptible to it in-vitro. Gerada et al. reported a liver transplant recipient with Salmonella related infectious aortitis and bacteraemia, who responded well to piperacillin/tazobactam treatment [42]. Thus, piperacillin/ tazobactam might be considered as one of the therapeutic options for S. arizonae infection.

During the 1980s, S. arizonae infection became an important issue in public health due to the emergence of many severe infection cases, and its association with extensive use of rattlesnake-based products $[10,19,28]$ mainly in areas with large Mexican-American populations in southwestern United States [1, 7, 13]. Approximately $70 \%$ of the 44 patients reported in previous studies (Table 2) mentioned a history of exposure to reptiles, especially snakes. Rattlesnake-based products are not common in Taiwan and we could not identify any specific animal contact history from the medical records of those patients. It is important to identify whether natural habitats of $S$. arizonae are present and whether $S$. arizonae infection is one of the zoonoses in Taiwan. Further studies are needed to identify the possible sources of this infection.

\section{Conclusions}

Our study showed that $S$. arizonae infection, although uncommon, is present in Taiwan, an area outside of typical endemic areas. In addition to previously reported risk factors, usage of acid suppressants, such as proton pump inhibitors and $\mathrm{H}_{2}$ blockers, might also predispose to $S$. arizonae infection. To treat $S$. arizonae infection, 


\section{third-generation cephalosporins might be more effective than ampicillin.}

\section{Abbreviations}

AIDS: Acquired immunodeficiency syndrome; ALS: Amyotrophic lateral sclerosis; ALT: Alanine aminotransferase; CHF: Congestive heart failure; CLSI: Clinical and laboratory standards institute; CRP: C-reactive protein; CYCH: Chia-Yi Christian hospital; DCM: Dilated cardiomyopathy; DM: Diabetes mellitus; F: Female; HBV: Hepatitis B; HTN: Hypertension; M: Male; NA: Not available; RA: Rheumatoid arthritis; SLE: Systemic lupus erythematosus; TMP/SMX: Trimethoprim/sulfamethoxazole; UTI: Urinary tract infection; WBC: White blood cell

\section{Acknowledgments}

We would like to acknowledge Management Information System Engineer Mrs. Fang-ling Kao for acquisition and analysis of data.

\section{Funding}

There were no external or internal sources of specific funding for this paper.

\section{Availability of data and materials}

The datasets supporting the conclusions of this article would be obtained by contacting the author at cimedin7@yahoo.com.tw.

\section{Authors' contributions}

YCL and JTW designed, executed, and supervised the study. YCL drafted the manuscript, and $\mathrm{MCH}$ and $\mathrm{SCH}$ helped writing of the article. SCH, HPW and MCL participated in collection, analysis and interpretation of the data. HLC carried out the literature review. YCL, MCH and JTW critically reviewed the manuscript. All authors read and approved the final manuscript.

\section{Competing interests}

The authors declare that they have no competing interests.

\section{Consent for publication}

Not applicable.

\section{Ethics approval and consent to participate}

The study was approved by the Institutional Review of Board of Chia-Yi Christian Hospital (CYCH-IRB No. 104035, 06/30/2015). The IRB waived both the informed consent due to the retrospective study design and the research posing no more than minimal risk.

\section{Author details}

'Department of Internal Medicine, Ditmanson Medical Foundation Chia-Yi Christian Hospital, Chia-Yi, Taiwan. ${ }^{2}$ Department of Pediatrics, Taipei Veterans General Hospital, Taipei, Taiwan. ${ }^{3}$ Department of Radiology, Taipei Veterans General Hospital, Taipei, Taiwan. ${ }^{4}$ School of Medicine, National Yang-Ming University, Taipei, Taiwan. ${ }^{5}$ Department of Nursing, Ditmanson Medical Foundation Chia-Yi Christian Hospital, Chia-Yi, Taiwan. 'Department of Laboratory Medicine, Ditmanson Medical Foundation Chia-Yi Christian Hospital, Chia-Yi, Taiwan. ${ }^{7}$ Department of Internal Medicine, National Taiwan University Hospital, No. 7 Chung-Shan South Road, Taipei 10002, Taiwan.

Received: 2 April 2016 Accepted: 1 December 2016 Published online: 09 December 2016

\section{References}

1. Riley KB, Antoniskis D, Maris R, Leedom JM. Rattlesnake capsule-associated Salmonella arizona infections. Arch Intern Med. 1988;148(5):1207-10.

2. Caldwell ME, Ryerson DL. Salmonellosis in Certain Reptiles. J Infect Dis. 1939;65(3):242-5

3. Tindall BJ, Grimont PA, Garrity GM, Euzeby JP. Nomenclature and taxonomy of the genus Salmonella. Int J Syst Evol Microbiol. 2005;55(1):521-4.

4. Di Bella S, Capone A, Bordi E, Johnson E, Musso M, Topino S, Noto P, Petrosillo N. Salmonella enterica ssp. arizonae infection in a 43-year-old Italian man with hypoglobulinemia: a case report and review of the literature. J Med Case Rep. 2011:5:323.

5. Seligmann E, Saphra L, Wassermann M. Occurrence of some unusual Salmonella types in man including a new type, Salmonella georgia. Am J Hyg. 1944;40:227-31
6. Andrews MD. Arizona group gastroenteritis. J Okla State Med Assoc. 1970:63(9):421-5.

7. Centers for Disease Control (CDC). Arizona hinshawii septicemia associated with rattlesnake powder-California. MMWR Morb Morta Wkly Rep. 1983;32(35):464-5.

8. Smilack JD, Goldberg MA. Bone and joint infection with Arizona hinshawii: report of a case and a review of the literature. Am J Med Sci. 1975;270(3):503-7.

9. Kolker S, Itsekzon T, Yinnon AM, Lachish T. Osteomyelitis due to Salmonella enterica subsp. arizonae: the price of exotic pets. Clin Microbiol Infect. 2012;18(2):167-70.

10. Bhatt BD, Zuckerman MJ, Foland JA, Polly SM, Marwah RK. Disseminated Salmonella arizona infection associated with rattlesnake meat ingestion. Am J Gastroenterol. 1989:84(4):433-5.

11. Quismorio Jr FP, Jakes JT, Zarnow AJ, Barber D, Kitridou RC. Septic arthritis due to Arizona hinshawii. J Rheumatol. 1983:10(1):147-50.

12. Keren DF, Rawlings Jr W, Murray HW, Leonard WR. Arizona hinshawii osteomyelitis with antecedent enteric fever and sepsis. A case report with a review of the literature. Am J Med. 1976;60(4):577-82.

13. Fainstein V, Yancey R, Trier P, Bodey GP. Overwhelming infection in a cance patient caused by Arizona hinshawii: its relation to snake pill ingestion. Am J Infect Control. 1982;10(4):147-53.

14. Cone LA, Boughton WH, Cone LA, Lehv LH. Rattlesnake capsule-induced Salmonella arizonae bacteremia. West J Med. 1990;153(3):315-6.

15. Noskin GA, Clarke JT. Salmonella arizonae bacteremia as the presenting manifestation of human immunodeficiency virus infection following rattlesnake meat ingestion. Rev Infect Dis. 1990;12(3):514-7.

16. Mclntyre Jr KE, Malone JM, Richards E, Axline SG. Mycotic aortic pseudoaneurysm with aortoenteric fistula caused by Arizona hinshawii. Surgery. 1982;91(2):173-7.

17. Hoag JB, Sessler CN. A comprehensive review of disseminated Salmonella arizona infection with an illustrative case presentation. South Med J. 2005:98(11):1123-9.

18. Arora S, Tyagi SC. Bacteremia due to Salmonella arizonae. J Assoc Physicians India. 1976;24(7):457-8.

19. Jacobson MA, Hahn SM, Gerberding JL, Lee B, Sande MA. Ciprofloxacin for Salmonella bacteremia in the acquired immunodeficiency syndrome (AIDS). Ann Intern Med. 1989;110(12):1027-9.

20. Krag D, Shean DB. Serious human infections due to bacilli of the Arizona group. Calif Med. 1959;90(3):230-3.

21. Kraus A, Guerra-Bautista G, Alarcon-Segovia D. Salmonella arizona arthritis and septicemia associated with rattlesnake ingestion by patients with connective tissue diseases. A dangerous complication of folk medicine. J Rheumatol. 1991;18(9):1328-31.

22. Petru MA, Richman DD. Arizona hinshawii infection of an atherosclerotic abdominal aorta. Arch Intern Med. 1981:141(4):537-8.

23. Schneider L, Ehlinger M, Stanchina C, Giacomelli MC, Gicquel P, Karger C, Clavert JM. Salmonella enterica subsp. arizonae bone and joints sepsis. A case report and literature review. Orthop Traumatol Surg Res. 2009;95(3):237-42.

24. Guckian JC, Byers EH, Perry JE. Arizona infection of man. Report of a case and review of the literature. Arch Intern Med. 1967;119(2):170-5.

25. Caravalho Jr J, McMillan VM, Ellis RB, Betancourt A. Endogenous endophthalmitis due to Salmonella arizonae and Hafnia alvei. South Med J. 1990:83(3):325-7.

26. Cortes E, Zuckerman MJ, Ho H. Recurrent Salmonella arizona infection after treatment for metastatic carcinoma. J Clin Gastroenterol. 1992;14(2):157-9.

27. Woolf GM, Runyon BA. Spontaneous Salmonella infection of high-protein noncirrhotic ascites. J Clin Gastroenterol. 1990;12(4):430-2.

28. Fleischman S, Haake DA, Lovett MA. Salmonella arizona infections associated with ingestion of rattlesnake capsules. Arch Intern Med. 1989;149(3):701. 705

29. Sharma J, Von Hoff DD, Weiss GR. Salmonella arizonae peritonitis secondary to ingestion of rattlesnake capsules for gastric cancer. J Clin Oncol. 1993;11(11):2288-9.

30. Babu K, Sonnenberg M, Kathpalia S, Ortega P, Swiatlo AL, Kocka FE. Isolation of salmonellae from dried rattlesnake preparations. J Clin Microbiol. 1990;28(2):361-2.

31. Casner PR, Zuckerman MJ. Salmonella arizonae in patients with AIDS along the U.S.-Mexican border. N Engl J Med. 1990:323(3):198-9.

32. Johnson RH, Lutwick LI, Huntley GA, Vosti KL. Arizona hinshawii infections. New cases, antimicrobial sensitivities, and literature review. Ann Intern Med. 1976;85(5):587-92. 
33. Baron EJ, Thomson RB. Specimen Collection, Transport, and Processing: Bacteriology. In: Versalovic J, Carroll KC, Funke G, Jorgensen JH, Landry ML, Warnock D, editors. Manual of Clinical Microbiology. Washington, DC: ASM press; 2011. p. 228-71.

34. Atlas RM, Synder JW. Reagents, Stains, and Media: Bacteriology. In: Versalovic J, Carroll KC, Funke G, Jorgensen JH, Landry ML, Warnock D, editors. Manual of Clinical Microbiology. Washington, DC: ASM press; 2011. p. 272-303.

35. Laboratory C, Institute S. Performance Standards for Antimicrobial Susceptibility Testing; twentieth Informational Supplement, M100-S20. CLSI: Wayne; 2010.

36. Clinical Laboratory and Standard Institute. Performance Standards for Antimicrobial Susceptibility Testing: twenty-third Information Supplement, M100-S23. Wayne: CLSI; 2013.

37. Kwon MH, Kang MI, Chun JY, Lim HW, Yeum YS, Kang YW, Kim YJ, Kim YK. A case of neck abscess caused by Salmonella serotype D in a patient with liver cirrhosis. Yonsei Med J. 2010;51(1):128-30

38. Jacobs C, Coss AE, Attaluri A, Valestin J, Rao SS. Dysmotility and proton pump inhibitor use are independent risk factors for small intestinal bacterial and/or fungal overgrowth. Aliment Pharmacol Ther. 2013;37(11):1103-11.

39. Wu HH, Chen YT, Shih CJ, Lee YT, Kuo SC, Chen TL. Association between recent use of proton pump inhibitors and nontyphoid salmonellosis: a nested case-control study. Clin Infect Dis. 2014;59(11):1554-8.

40. Lindsay KL, Canawati HN. Spontaneous Arizona hinshawii peritonitis in cirrhosis with ascites. Gastroenterology. 1981;81(2):349-51.

41. Wang JY, Hwang JJ, Hsu CN, Lin LC, Hsueh PR. Bacteraemia due to ciprofloxacin-resistant Salmonella enterica serotype Choleraesuis in adult patients at a university hospital in Taiwan, 1996-2004. Epidemiol Infect. 2006;134(5):977-84.

42. Gerada J, Ganeshanantham G, Dawwas MF, Winterbottom AP, Sivaprakasam R, Butler AJ, Alexander GJ. Infectious aortitis in a liver transplant recipient. Am J Transplant. 2013;13(9):2479-82.

\section{Submit your next manuscript to BioMed Central and we will help you at every step:}

- We accept pre-submission inquiries

- Our selector tool helps you to find the most relevant journal

- We provide round the clock customer support

- Convenient online submission

- Thorough peer review

- Inclusion in PubMed and all major indexing services

- Maximum visibility for your research

Submit your manuscript at www.biomedcentral.com/submit

) Biomed Central 